https://doi.org/10.15407/dopovidi2021.05.114

UDC 616.379-008.64:616.12:616.98

M. D. Tronko, https://orcid.org/0000-0001-7421-0981

V. V. Pushkarev, https://orcid.org/0000-0001-5940-5510

L. K. Sokolova, https://orcid.org/0000-0003-0011-0106

S. A. Cherviakova, https://orcid.org/0000-0002-6917-5736

Yu. B. Belchina, https://orcid.org/0000-0002-4289-8977

O. I. Kovzun, https://orcid.org/0000-0001-8164-7671

V. M. Pushkarev, https://orcid.org/0000-0003-0347-7771

V.P. Komisarenko Institute of Endocrinology and Metabolism of the NAMS of Ukraine, Kyiv E-mail: pushkarev.vm@gmail.com

\title{
Effects of COVID-19, diabetes mellitus, and cardiovascular diseases on insulin receptor substrate-1 amount in the blood plasma of patients
}

Presented by Corresponding Member of the NAS of Ukraine M.D. Tronko

Insulin receptor substrate (IRS) is a key adapter protein mediating effects of insulin and insulin-like growth factors (IGF) in cells. IRS-1 is a member of the insulin receptor substrate family, which is associated with tumor initiation and progression. The aim of the study is to determine the level of IRS-1 in the blood of patients $(n=81)$ with diabetes mellitus and COVID-19. IRS-1 was determined with enzyme-linked immunosorbent assay (ELISA) (Elabscience, USA). The measurements were performed at an optical wavelength of $450 \mathrm{~nm}$. The level of IRS-1 in the blood plasma of patients with COVID-19 was much (from 3.5 to more than 6 times) higher than that in the blood of healthy people. The IRS-1 amounts in COVID-19 patients with diabetes and diabetes + CVD were significantly higher than in patients with COVID-19 without concomitant diseases. The level of IRS-1 in blood plasma may be one of the promising markers of COVID-19.

Keywords: Insulin receptor substrate-1, COVID-19, diabetes mellitus, cardiovascular diseases.

Insulin receptor substrate (IRS) is a key adapter protein mediating effects of insulin and insulin-like growth factors (IGF) in cells $[1,2]$. The PTB (phosphotyrosine binding domains) and $\mathrm{PH}$ (pleckstrin homology domain) domains are involved in the interaction of the receptor with the IRS. Phosphorylated IRS is a platform for the propagation of insulin signals in the cell, which it shares with other receptor tyrosine kinases, such as IGF-1R, signaling network of which is

Ци ту вання: Tronko M.D., Pushkarev V.V., Sokolova L.K., Cherviakova S.A., Belchina Yu.B., Kovzun O.I., Pushkarev V.M. Effects of COVID-19, diabetes mellitus, and cardiovascular diseases on insulin receptor substrate-1 amount in the blood plasma of patients. Допов. Нащ. акад. наук Укр. 2021. № 5. С. 114-117. https://doi.org/10.15407/dopovidi2021.05.114 
Plasma IRS-1 levels of patients with diabetes, CVD and COVID-19. 1 - control $(n=7) ; 2$ - patients with diabetes mellitus $(n=60) ; 3-$ patients with COVID-19 $(n=5) ; 4$ - patients with diabetes and COVID-19 $(n=16) ; 5$ - diabetic patients with COVID-19 and CVD $(n=5) . M \pm m .^{*}$ - differences from control are significant, $P<0.05$; ** $-P<$ $<0.0001 ;+-$ differences from previous group are significant, $P<0.05-0.001$

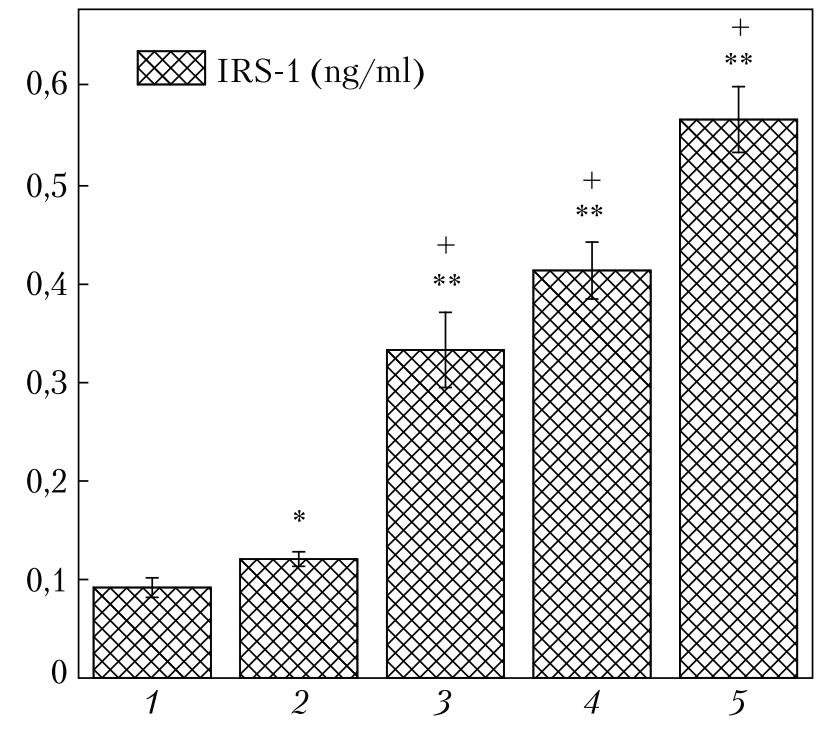

almost indistinguishable from that of insulin [3]. IRS-1 is a member of the insulin receptor substrate family, which is also associated with tumor initiation and progression [4-6]. Overexpression of IRS-1 promotes the growth of cells, inhibits autophagy, reduces oxidative stress-induced autophagy, and diminishes oxidative stress-mediated autophagy-dependent cell death [7, 8].

Materials and Methods. The study was conducted in the diabetology department of the Institute. The study protocol was approved by the Institute's ethics committee. All patients signed informed consent to conduct further diagnostic and research study.

Blood was obtained by standard venipuncture and stored in EDTA vacutainer tubes. Plasma was separated by centrifugation within $10 \mathrm{~min}$ after blood sampling. The samples were stored at $-80{ }^{\circ} \mathrm{C}$ until use. IRS-1 was determined $(n=81)$ using enzyme-linked immunosorbent assay (ELISA) kit (Elabscience, USA). The measurement was carried out at an optical wavelength of $450 \mathrm{~nm}$ on an immunoenzymatic plate analyzer Stat Fax 3200 (Awareness Technology, USA).

Glycated hemoglobin was determined using one HbA1c FS kit (DiaSys Diagnostic Systems GmbH, Germany). The measurement was carried out at an optical wavelength of $660 \mathrm{~nm}$.

Statistical analysis and data presentation were performed using the Origin 7.0 software. The results of the study are presented as $M \pm \mathrm{m}$. To compare the data groups, Student's $t$-test was used. Values of $P \leqslant 0.05$ were considered as significant.

Results and Discussion. The blood plasma of 60 type 2 diabetes patients and 21 patients with diabetes, cardiovascular diseases (CVD) and COVID-19 was used. As a control, we used the blood of healthy people $(n=7)$ without concomitant diseases, representative of age. The level of Hb1Ac in diabetic patients was $9.62 \pm 0.27$; BMI $-30.69 \pm 1.06 \mathrm{~kg} / \mathrm{m}^{2}$. The fasting glucose content in the blood of patients with COVID-19 and diabetes was $9.6 \pm 0.92 \mathrm{mmol} / \mathrm{l}$, at the time of discharge $-6.72 \pm 0.62 \mathrm{mmol} / \mathrm{l}$. Average $\mathrm{O}_{2}$ saturation was $87.3 \pm 0.7 \%$ that indicates a severe course of the disease.

The average level of IRS- 1 in the blood of healthy people is below $0.1 \mathrm{ng} / \mathrm{ml}$ (Fig.). In diabetic patients, this indicator is higher $-0.12 \mathrm{ng} / \mathrm{ml}$. The amount of IRS-1 in the blood of people with COVID-19 is substantially higher $-0.33 \mathrm{ng} / \mathrm{ml}$. In patients with diabetes and COVID-19, 
the content of IRS-1 in the blood is more than $0.4 \mathrm{ng} / \mathrm{ml}$ that is more than 4 times higher than normal values. In the blood of diabetic patients with COVID-19 and CVD the level of IRS-1 further increased to $0.57 \mathrm{ng} / \mathrm{ml}$. Thus, the level of IRS-1 rises with the increase in the number of concomitant with COVID-19 diseases.

As can be seen from our data and the results obtained by other authors, the level of IRS in the blood of healthy people is quite low. However, for serious illnesses such as cancer, it more than doubles. A highly significant increase was found in serum IRS-1 of nasopharyngeal carcinoma compared with that of healthy individuals. It might be potential biomarkers in the diagnosis of cancer [8]. In the blood of patients with COVID-19 and concomitant diseases, the quantity of IRS-1 increased from 3.5 to more than 6 times. It is still difficult to assume what is the reason for the growth of this substrate and what is the mechanism of its appearance in blood plasma. Most likely, its source is blood cells or tumor cells in the case of cancer. The physiological roles of IRSs are not limited to glucose metabolism and growth. It is known that, in addition to its participation in mediating the action of growth factors, IRS is involved in other signaling mechanisms that are still insufficiently studied. IRS-1 maintains vascular health, and IRS-1 and IRS-2 governed bone turnover and adipocyte differentiation [9-11].

Conclusions. The level of IRS-1 in the blood plasma of patients with COVID-19 was much higher than in the blood of healthy people. IRS-1 amounts in COVID-19 patients with diabetes and diabetes + cardiovascular diseases are significantly higher than in patients with COVID-19 without concomitant diseases.

The level of IRS-1 may be one of the promising markers of COVID-19.

\section{REFERENCES}

1. Tronko, N. D., Pushkarev, V. M., Sokolova, L. K., Pushkarev, V. V. \& Kovzun, O. I. (2018). Molecular mechanisms of pathogenesis of diabetes and its complications. Kyiv: Publishing house Medkniga (in Russian).

2. Tronko, N. D., Kovzun, E. I., Pushkarev, V. V., Sokolova, L. K. \& Pushkarev, V. M. (2018). Reception and intracellular mechanisms of insulin action (part 1). Endokrynologia, 23, No. 3, pp. 269-280 (in Russian).

3. Semple, R. K. (2016). EJE PRIZE 2016: How does insulin resistance arise, and how does it cause disease? Human genetic lessons. Eur. J. Endocrinol., 174, No. 5, pp. R209-223.

4. Esposito, D. L., Aru, F., Lattanzio, R., Morgano, A., Abbondanza, M., Malekzadeh, R., Bishehsari, F., Valanzano, R., Russo, A., Piantelli, M., Moschetta, A., Lotti, L. V. \& Mariani-Costantini, R. (2012). The insulin receptor substrate 1 (IRS1) in intestinal epithelial differentiation and in colorectal cancer. PLoS One, 7, pp. e36190.

5. Porter, H. A., Perry, A., Kingsley, C., Tran, N. L. \& Keegan, A. D. (2013). IRS1 is highly expressed in localized breast tumors and regulates the sensitivity of breast cancer cells to chemotherapy, while IRS2 is highly expressed in invasive breast tumors. Cancer Lett., 338, pp. 239-248.

6. Luo, J., Wen, Q., Li, J., Xu, L., Chu, S., Wang, W., Shi, L., Xie, G., Huang, D. \& Fan, S. (2014). Increased expression of IRS-1 is associated with lymph node metastasis in nasopharyngeal carcinoma. Int. J. Clin. Exp. Pathol., 7, pp. 6117-6124.

7. Sun, X., Chen, Y., Tan, J. \& Qi, X. (2018). Serum IRS-1 acts as a novel biomarker for diagnosis in patients with nasopharyngeal carcinoma. Int. J. Clin. Exp. Pathol., 11, No. 7, pp. 3685-3690.

8. Chan, S. H., Kikkawa, U., Matsuzaki, H., Chen, J. H. \& Chang, W. C. (2012). Insulin receptor substrate-1 prevents autophagy-dependent cell death caused by oxidative stress in mouse NIH/3T3 cells. J. Biomed. Sci., 19, pp. 64.

9. Hakuno, F., Fukushima, T., Yoneyama, Y., Kamei, H., Ozoe, A., Yoshihara, H., Yamanaka, D., Shibano, T., Sone-Yonezawa, M., Yu, B. C., Chida, K. \& Takahashi, S. (2015). The novel functions of high-molecular-mass complexes containing insulin receptor substrates in mediation and modulation of insulin-like activities: 
emerging concept of diverse functions by IRS-associated proteins. Front. Endocrinol. (Lausanne), 6, pp. 73. https://doi.org/10.3389/fendo.2015.00073

10. Reuveni, H., Flashner-Abramson, E., Steiner, L., Makedonski, K., Song, R., Shir, A., Herlyn, M., Bar-Eli, M. \& Levitzki, A. (2013). Therapeutic destruction of insulin receptor substrates for cancer treatment. Cancer Res., 73, No. 14, pp. 4383-4394. https://doi.org/10.1158/0008-5472.CAN-12-3385

11. Mardilovich, K., Pankratz, S. L. \& Shaw, L. M. (2009). Expression and function of the insulin receptor substrate proteins in cancer. Cell Commun. Signal., 7, pp. 14. https://doi.org/10.1186/1478-811X-7-14

Received 09.06.2021

М. Д. Тронько, https://orcid.org/0000-0001-7421-0981

В. В. Пушкаръов, https://orcid.org/0000-0001-5940-5510

Л. К. Соколова, https://orcid.org/0000-0003-0011-0106

С. А. Червякова, https://orcid.org/0000-0002-6917-5736

Ю. Б. Бельчина, https://orcid.org/0000-0002-4289-8977

О. I. Ковзун, https://orcid.org/0000-0001-8164-7671

В. М. Пушкарьов, https://orcid.org/0000-0003-0347-7771

ДУ “Інститут ендокринології та обміну речовин

ім. В.П. Комісаренка НАМН України”, Київ

E-mail: pushkarev.vm@gmail.com

ВПЛИВ COVID-19, ЦУКРОВОГО ДІАБЕТУ

ТА СЕРЦЕВО-СУДИННИХ ЗАХВОРЮВАНЬ

НА КІЛЬКІСТЬ СУБСТРАТУ РЕЦЕПТОРА ІНСУЛІНУ-1

У ПЛАЗМІ КРОВІ ПАЦІЕНТІВ

Субстрат рецепторів інсуліну (IRS) є ключовим адаптерним білком, що опосередковує ефекти інсуліну та інсуліноподібних факторів росту (IGF) у клітинах. IRS-1 є одним із членів сімейства субстратів рецепторів інсуліну, також пов'язаний з ініціацією та прогресуванням пухлини. Досліджено рівень IRS-1 у крові пацієнтів $(n=81)$ із цукровим діабетом, серцево-судинними захворюваннями та COVID-19. Рівень IRS-1 визначали за допомогою імуноферментного аналізу (ELISA) (Elabscience, CША). Вимірювання проводили при оптичній довжині хвилі 450 нм. Показано, що рівень IRS-1 у плазмі крові пацієнтів 3 COVID-19 був набагато (від 3,5 до більш ніж у 6 разів) вищим, ніж у крові здорових людей. Кількість IRS-1 у пацієнтів з COVID-19 і діабетом та діабетом і серцево-судинними захворюваннями вірогідно вища, ніж у пацієнтів з COVID-19 без супутніх захворювань. Рівень IRS-1 у плазмі крові може бути одним із перспективних маркерів COVID-19.

Ключові слова: субстрат інсулінового рещептора-1, COVID-19, цукровий діабет, серцево-судинні захворювання. 


\section{Інформація для авторів журналу “Доповіді Національної академії наук України”}

Журнал публікує статті науковців НАН України та закладів вищої освіти України зі спеціальностей: математика, інформатика та кібернетика, механіка, фізика, технічні науки (енергетика, теплофізика, матеріалознавство), науки про Землю, хімія, біологія, біохімія, біофізика, медицина, екологія.

Стаття повинна мати мотивоване представлення дійсного члена або члена-кореспондента НАН України з відповідної спеціальності. До статті додається супровідний лист організації, в якій виконано дослідження.

Журнал друкує не більше трьох повідомлень одного автора на рік. Це правило не поширюється на дійсних членів та членів-кореспондентів НАН України.

У разі додаткового рецензування та доопрацювання статті датою надходження вважається дата одержання редакцією її остаточного тексту. Прохання редакції про доопрацювання не означає, що стаття прийнята до друку; після доопрацювання вона знову розглядається редколегією. У разі відмови в публікації редколегія залишає за собою право не повертати автору оригінал статті.

Статті публікуються українською або англійською мовою. Автор зазначає рубрику, в якій має публікуватися стаття, індекс за Універсальною десятковою класифікацією; електронну адресу (адреси), ORCID.

\section{Зразок заголовка:}

УДК 517.927

В.А. Михайлець ${ }^{1}$, https://orcid.org/0000-0002-1332-1562

Т.Б. Скоробогач ${ }^{2}$, https://orcid.org/0000-0002-0119-8966

${ }^{1}$ Інститут математики НАН України, Київ

${ }^{2}$ НТУ України “Київський політехнічний інститут ім. Ігоря Сікорського”

E-mail: mikhailets@imath.kiev.ua, tetianaskorobohach@gmail.com

Фредгольмові крайові задачі з параметром

у просторах Соболєва-Слободецького

Представлено членом-кореспондентом НАН Украӥни А.Н. Кочубеєм

Обсяг статті не повинен перевищувати восьми сторінок журналу (включаючи список літератури - до 15 поз., таблиці, рисунки - до 4). Текст має бути набраний через 1,5 інтервала, розмір шрифту 14 пт. Фізичні величини наводяться в одиницях СІ. Наукова термінологія повинна відповідати сучасним вимогам.

Резюме подаються українською ( 900 знаків) та англійською ( $\approx 900$ знаків) мовами 3 ключовими словами (обов'язково вказати написання прізвищ та ініціалів, назву статті та організації (організацій) двома мовами), e-mail, ORCID:

\section{Зразок:}

V.V. Semenov, https://orcid.org/0000-0002-3280-8245

D.S. Siryk, https://orcid.org/0000-0002-8828-6861

O.S. Kharkov, https://orcid.org/0000-0002-9049-4846

Taras Shevchenko National University of Kyiv

E-mail: semenov.volodya@gmail.com, sirykds@gmail.com,

olehharek@gmail.com

CONVERGENCE OF THE OPERATOR EXTRAPOLATION METHOD

текст резюме

Keywords: variational inequality, pseudo-monotonicity, sequential weak continuity, Bregman divergence, operator extrapolation, adaptivity, weak convergence. 